\title{
Determination of Cefuroxime Axetil and Cefixime Trihydrate in Pharmaceutical Dosage Forms by RP-HPLC Method
}

\author{
Bashir Elias \\ Ph.D. in Analytical Chemistry Department, Al-Baath University, Homs, Syria \\ Mohammad Anas Alfeen \\ Ph. D Student in Analytical Chemistry, Al-Baath University, Homs, Syria
}

\begin{abstract}
A High Performance liquid chromatographic method was developed for the determination of Cephalosporins like as: Cefuroxime axetil, Cefixime trihydrate, in pharmaceutical dosage forms. Isocratic separation was performed on an Enable C18 column $(250 \mathrm{~mm}$ x $4.6 \mathrm{~mm}, 5.0 \mu \mathrm{m})$ using Triethylamine: Methanol: Acetonitrile: Ultra Pure Water (2: 10: 20: $68 \mathrm{v} / \mathrm{v} \%$ ) as the mobile phase at a flow rate of $1.0 \mathrm{ml} / \mathrm{min}$. The PDA detection wavelength was set at $265 \mathrm{~nm}$. The linearity was observed over a concentration range of $0.1-80 \mu \mathrm{g} / \mathrm{ml}$ for HPLC method (correlation coefficient $=0.999)$. The developed methods were validated according to ICH guidelines. The relative standard deviation values for the method precision studies were $<2 \%$, and the accuracy was $>99 \%$. The developed method was used successfully for the determination of Cefuroxime axetil, Cefixime trihydrate, in Capsule, Tablet and dry syrup formulations.
\end{abstract}

Keywords: Cefuroxime axetil (CA), Cefixime trihydrate (CT), HPLC.

\section{Introduction}

Cefuroxime axetil, (CA): 1-Hydroxyethyl $(6 R, 7 R)$-7-[2-(2-furyl)glyoxylamido]-3-(hydroxymethyl)-8-oxo-5-thia1-azabicyclo[4.2.0] oct-2-ene-2-carboxylate (Fig. 1) is a second generation cephalosporin antibiotic [1].

Cefixime trihydrate, $(\mathrm{CT}):(6 R, 7 R)-7-\{[(2 R)$-2-amino-2-phenylacetyl]amino $\}$-3-methyl-8-oxo-5-thia-1azabicyclo[4.2.0] oct-2-ene-2-carboxylic acid hydrate (Fig. 2) is a third generation cephalosporin antibiotic [1].

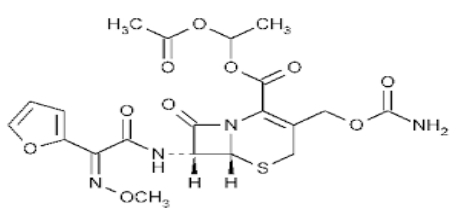

(Fig. 1)

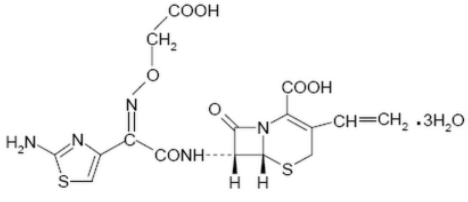

(Fig. 2)

It is used in the treatment of susceptible infections of the respiratory tract, urinary tract, and skin.

$\mathrm{CF}, \mathrm{CT}$ have been found to reduce the corrosion of mild steel in hydrochloric acid solution [2]. According to literature surveys, there are different analytical methods reported for the determination of CF, CT. It includes UV-Visible spectroscopy [3-12], chemiluminescence [13], near infrared spectroscopy [14], potentiometry [15], polarography [16, 17], HPLC [18-26], gel filtration chromatography [27], HPLC [28], capillary zone electrophoresis [29], LC-MS [30, 31], and MS [32] methods. But no analytical methods are reported for the determination of CF, CT in dry syrup formulation using the mobile phase Triethylamine: Methanol: Acetonitrile: Ultra Pure Water (2: 10: 20: $68 \mathrm{v} / \mathrm{v} \%$ ) by HPLC (High Performance liquid chromatography). So a successful attempt was made to develop and validate a fast, simple, precise, and accurate HPLC method for the determination of CF, CT in Capsule, Tablet and Syrup formulation. Specificity and stability parameters for the drug were assessed according to $\mathrm{ICH}[33]$.

\section{Experimental and Chemical Reagents}

Cefuroxime axetil (CA), Cefixime trihydrate (CT); (purity of all $>99.9 \%$ ) was obtained as a gift sample from Parabolic Pharmaceuticals Ltd., India. Methanol (Merck Ltd., Mumbai, India) was of HPLC grade. Analytical grade Methanol, Acetonitrile, Triethylamine (Merck GmpH). The Ultra Pure water for HPLC was obtained by using the TKA Water Purification System, Germany. The Capsule formulation (CT) containing $400 \mathrm{mg} \backslash \mathrm{Cap}$. The Tablet formulation (CF) containing 500mg $\backslash$ Tab. The dry Syrup formulation (CF),(CT)containing $125 \mathrm{mg} \backslash 5 \mathrm{~mL}$, $250 \mathrm{mg} \backslash 5 \mathrm{~mL}, 100 \mathrm{mg} \backslash 5 \mathrm{~mL}, 200 \mathrm{mg} \backslash 5 \mathrm{~mL}$, was bought from the local market.

\section{Instrumention}

Quantitative HPLC was performed on a binary gradient with MERCK-HITACHI Prominence La Chrom pumps, with a $20 \mu \mathrm{l}$ sample injection loop (Auto) and L-2455 PDA detector. The signal was recorded and integrated using EZ Chrom Software. An Enable C18, $(250 \mathrm{~mm} \times 4.6 \mathrm{~mm}$ i.d. particle size $5 \mu \mathrm{m})$ was used for separation. 
Chromatographic analysis was carried out at ambient temperature on the column using the Triethylamine: Methanol: Acetonitrile: Ultra Pure Water (2: 10: 20: $68 \mathrm{v} / \mathrm{v} \%$ ) as the mobile phase at a flow rate of $1.0 \mathrm{ml} / \mathrm{min}$ in isocratic mode. The PDA detection was carried out at $265 \mathrm{~nm}$.

\section{Preparation of Standard and Sample Solution}

Standard stock solutions of CF, CT were prepared by transferring $100 \mathrm{mg}$ of the drug into two separate $100 \mathrm{ml}$ volumetric flasks having $10 \mathrm{ml}$ of diluents and were ultrasonicated for 5 minutes. Finally the volume was made up with suitable diluents, which gave $1000 \mu \mathrm{g} \backslash \mathrm{mL}$ solutions. Powder (Capsule, Tablet and dry Syrup) equivalent to $100 \mathrm{mg}$ of $\mathrm{CF}$, CT was accurately measured and transferred into two separate $100 \mathrm{ml}$ volumetric flasks, containing $10 \mathrm{ml}$ of diluents and ultrasonicated for 20 minutes; the volume was made up and mixed well. Solutions were filtered by a $0.2 \mu \mathrm{m}$ filter to remove particulate matter, if any. The filtered solutions were properly diluted for analysis as already described. The drug present in the sample solutions was calculated by using the calibration curves. All the solutions were stored at $2-8^{\circ} \mathrm{C}$ for future use.

\section{Method Validation}

\subsection{Specificity}

The specificity of the HPLC method was determined by checking the interference of any of the possible degradation products and Absorbances produced during study of CF, CT. The study of the drug was carried out with Methanol, Triethylamine, Ultra Pure Water for discovering the stability nature of the drug. The degraded samples were prepared by taking suitable aliquots of the drug solution, and then undertaking the respective stress testing procedures for each solution. After the fixed time period, the stressed test solutions were diluted with the mobile phase. For every stress condition, a solution of concentration $50 \mu \mathrm{g} \backslash \mathrm{mL}$ of $\mathrm{CF}$, CT was prepared. The specific stress conditions are described as follows.

\subsection{Linearity}

An twelve-point $(0.1,0.5,1.0,5.0,10,20,30,40,50,60,70$ and $80 \mu \mathrm{g} \backslash \mathrm{mL})$ calibration curves were prepared for the HPLC methods. The peak area for the HPLC was obtained by injecting $20 \mu \mathrm{l}$ of the drug solution into the column. Calibration curves were plotted by taking the peak area curve on the y-axis and the concentration $(\mu \mathrm{g} \backslash \mathrm{mL})$ on the $\mathrm{x}$-axis.

\subsection{Precision}

The intraday and interday precision study was carried out to check the reproducibility of the results. A concentration of $(15,20,25) \mu \mathrm{g} \backslash \mathrm{mL}$ and $30 \mu \mathrm{g} \backslash \mathrm{mL}$ of, $\mathrm{CF}, \mathrm{CT}(\mathrm{n}=3)$ were analyzed to find out relative standard deviation (RSD) for HPLC methods.

\subsection{Accuracy}

To check the accuracy of the proposed method, recovery studies were carried out at 80,100 , and $120 \%$ of the test concentration. The recovery study was performed three times at each level. The amount of CF, CT present in the sample was calculated using the calibration curves.

\subsection{Robustness}

The robustness of the HPLC method was studied by deliberately changing the method parameters like flow rate of the mobile phase, detection wavelength, and organic phase composition. A series of system suitability parameters like retention time, theoretical plates, and tailing factor were determined for each changed condition according to $\mathrm{ICH}[33]$.

\subsection{Limit of Detection and Limit of Quantitation}

The LOD and LOQ were determined separately according to the ICH guidelines. For the HPLC method, concentrations providing a signal-to-noise ratio 3:1 and 10:1 were considered as the LOD and LOQ, respectively.

\subsection{Results and Discussion}

Optimization of the mobile phase was carried out based on the tailing factor and theoretical plates obtained for CF, CT. During the trial runs, the drug was tested with different mobile phase compositions like (Triethylamine: Ultra pure water: Acetonitirle: Methanol $v \backslash v \%)$ at various compositions (25:25:25:25 v $\backslash \mathrm{v} \%),(10: 20: 65: 5 \mathrm{v} \backslash \mathrm{v} \%)$, and $(10: 20: 68: 2 \mathrm{v} / \mathrm{v} \%)$ and flow rates $(0.5,1.0$, and $1.2 \mathrm{~mL} / \mathrm{min})$. The mobile phase consisting of Triethylamine: Methanol: Acetonitrile: Ultra Pure Water (2: 10: 20: $68 \mathrm{v} / \mathrm{v} \%$ ) at a flow rate of $1.0 \mathrm{ml} \backslash \mathrm{min}$ was selected which gave a sharp, symmetric peak for CF, CT. The retention time for CF, CT was found to be $(3.98,3.67,3.16 \mathrm{~min})$ respectively. The run time was $5 \mathrm{~min}$. The tailing factor for $\mathrm{CF}, \mathrm{CT}$ was found to be $(1.48,1.43,1.26)$. PDA detection was carried out at $265 \mathrm{~nm}$. The separation was carried out at room temperature. Fig.3 (A), (B) 
Respectively.
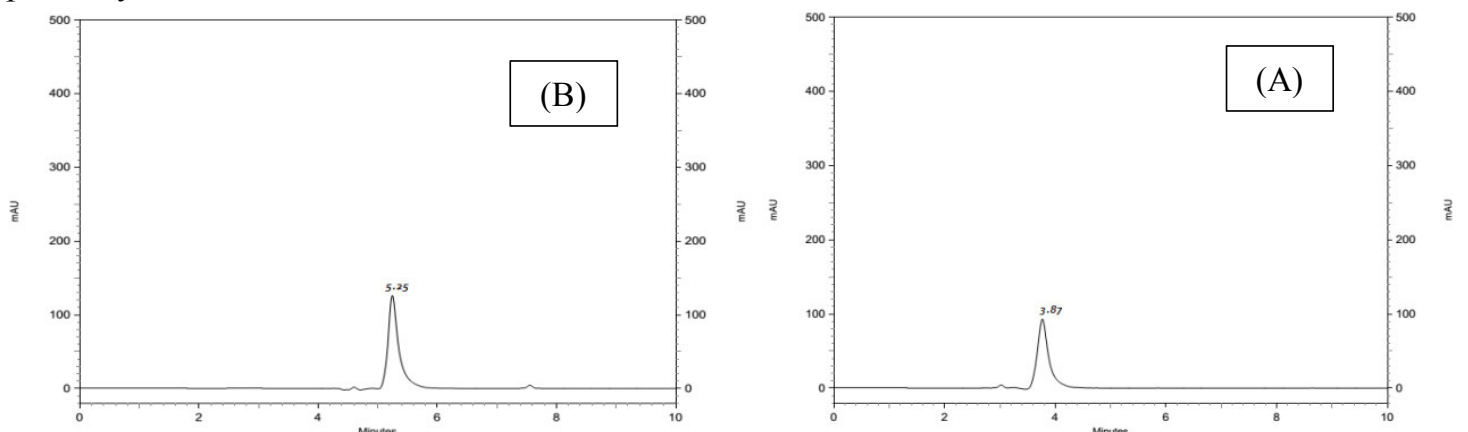

\subsubsection{Specificity}

Fig. 3. Chromatograms of CF, CT for Method (A), (B) Respectively

To evaluate the specificity, a PDA detector was applied to find out the peak purity of the chromatographic peaks obtained for the stress-treated drug solution. Peak purity results are indicative for finding out the peak homogeneity. The specificity of the HPLC method was determined by checking the interference of any of the possible degradation products and Absorbances produced during study of CF, CT. The study of the drug was carried out with Methanol, Triethylamine, Ultra Pure Water for discovering the stability nature of the drug. The degraded samples were prepared by taking suitable aliquots of the drug solution, and then undertaking the respective stress testing procedures for each solution. The UV spectrums (Fig. 4) obtained for the blank and placebo show no interference due to the solvent used and presence of the commonly used excipients suggesting the specificity of the two methods.
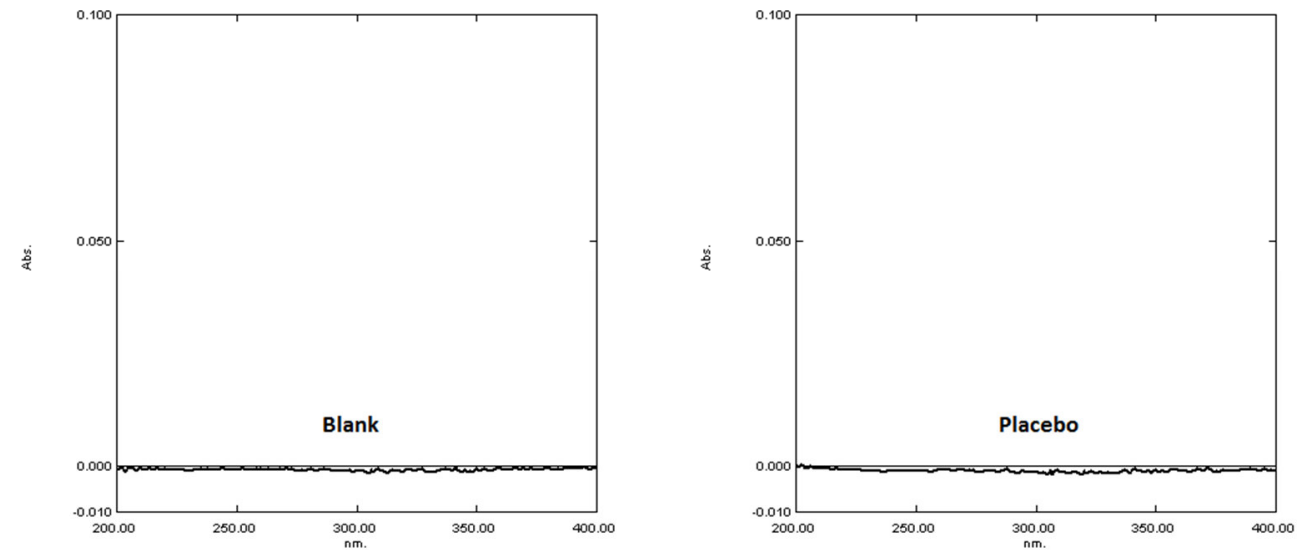

Fig. 4. UV Spectrum of Blank Solution (left) and of Placebo Solution (right)

5.8.2 Linearity

The calibration curves were found to be linear over a concentration range of $0.1-80 \mu \mathrm{g} \backslash \mathrm{mL}$ for methods (correlation coefficient 0.999 for all the methods). The method parameters (overlay chromatograms) and regression data(Linearity series) are shown in (Fig. 5). (Fig. 6) Linearity of CF, (Fig. 7) Linearity of CT, Table 1 for regression data .

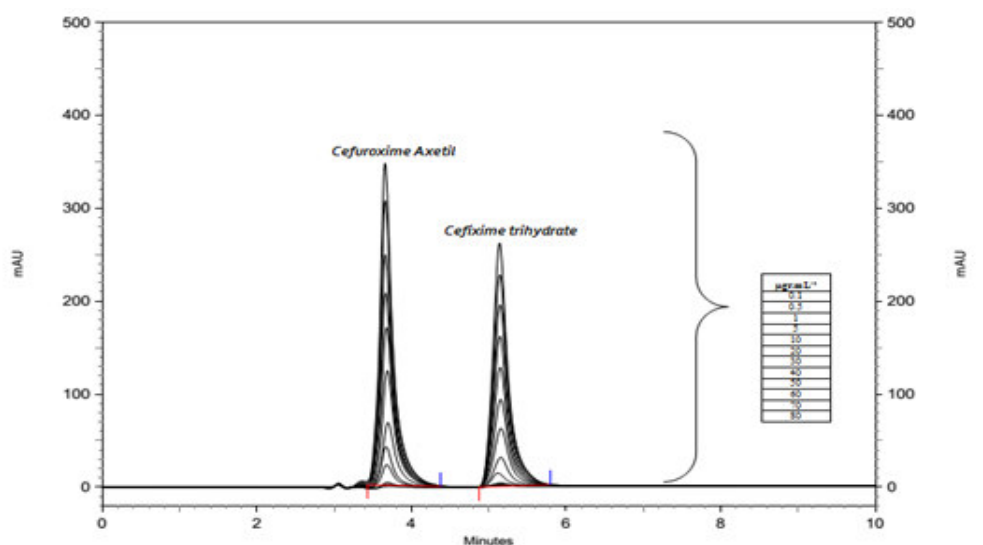

Fig. 5. Overlay Chromatograms of CF, CT, linearity rang $(0.1-80) \mu \mathrm{g} \backslash \mathrm{mL}$ 


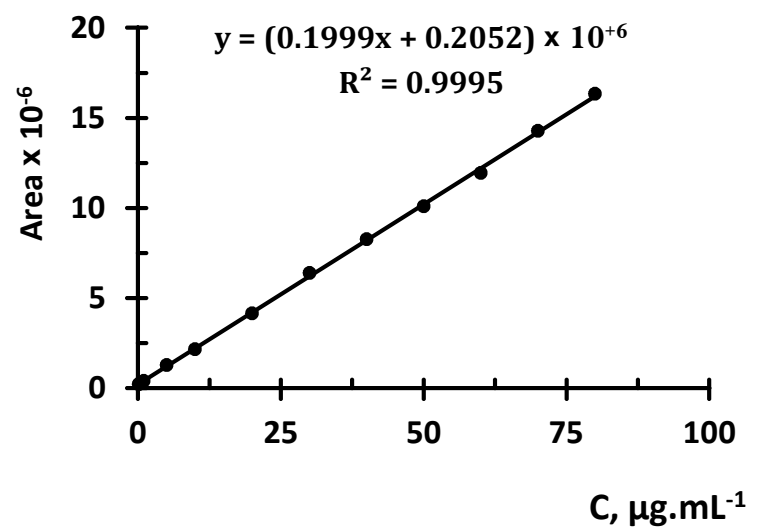

Fig. 6. Linearity of CF (0.1-80) $\mu \mathrm{g} \backslash \mathrm{mL}$

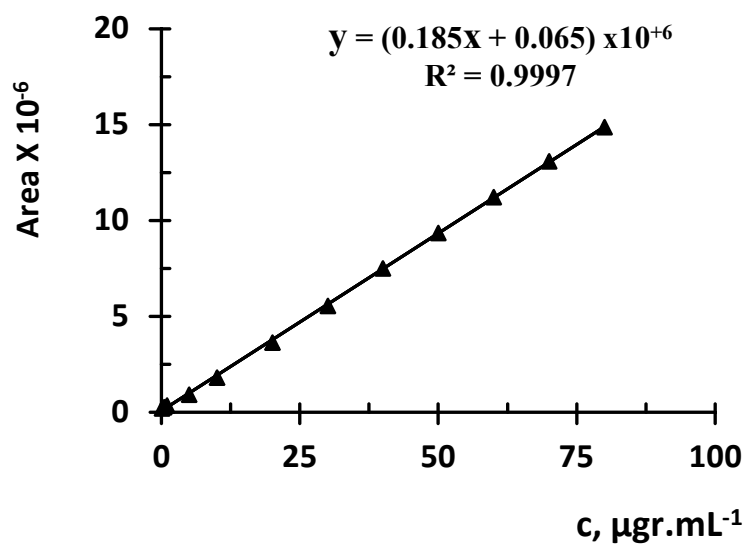

Fig. 7. Linearity of CT (0.1-80) $\mu \mathrm{g} \backslash \mathrm{mL}$

Tab. 1. Analysis of method parameters and regression data

\begin{tabular}{||c||c||c||}
\hline Parameter & $\begin{array}{c}\text { Cefuroxime axetil, } \\
\text { (CF) }\end{array}$ & $\begin{array}{c}\text { Cefixime trihydrate, } \\
\text { (CT) }\end{array}$ \\
\hline \hline Slope & $0.199 \times 10^{+6}$ & $0.185 \times 10^{+6}$ \\
\hline \hline Intercept & $0.205 \times 10^{+6}$ & $0.065 \times 10^{+6}$ \\
\hline \hline Correlation Coefficient & 0.9995 & 0.9997 \\
\hline \hline Detection Wavelength, $\mathbf{n m}$ & \multicolumn{2}{|c|}{265} \\
\hline \hline Linear rang, $\boldsymbol{\mu g} \backslash \mathbf{m L}$ & \multicolumn{2}{|c|}{$0.1-80$} \\
\hline
\end{tabular}

\subsubsection{Precision}

The methods were found to be precise as the RSD (\%) values for the precision studies were well below $2 \%(\mathrm{n}=3)$. The results are shown in Table 2.

\subsubsection{Accuracy}

The accuracy of the developed methods was found out by the standard addition method. High recovery values suggest that all three methods are accurate. The results are shown in Table 2.

\subsubsection{Limit of Detection and Limit of Quantitation}

The LOD and LOQ values shown in Table 2 suggest that the developed methods are sensitive to determine CF, CT.

Tab. 2. Summary of validation parameters

\begin{tabular}{||c||c||c||c|c||}
\hline \hline Parameter & Accuracy(recover), $\%$ & $*$ Precision(RSD), \% & LOD, $\boldsymbol{\mu g} / \mathbf{m l}$ & LOQ, $\boldsymbol{\mu g} / \mathbf{m l}$ \\
\hline \hline Cefuroxime axetil, (CF) & $100.96 \%$ & 0.28 & 0.87 & 2.66 \\
\hline \hline Cefixime trihydrate, (CT) & $100.75 \%$ & 0.98 & 0.67 & 2.05 \\
\hline \hline
\end{tabular}

* Average of three determination at each level.

\subsubsection{Robustness}

The HPLC method was found to be robust under deliberate changes in the mobile phase flow rate $( \pm 0.1 \mathrm{~mL} / \mathrm{min})$, detection wavelength $( \pm 5 \mathrm{~nm})$, and organic phase composition $( \pm 2 \%)$. The results of system suitability for the robustness study are shown in Table 2. For the UV spectroscopic methods, changing the slit width shows no significant effect on absorbance, indicating the robustness of the developed methods. No significant changes were obtained in the content of CF, CT during the solution stability studies by the developed methods. The recoveries for the solution stability by Method was found to be $100.96 \%, 100.75 \%$, respectively.

\subsubsection{Analysis of Commercial Dry Syrup Formulation}

The developed methods were successfully applied for the determination of CF, CT in the Tablet, Capsule, dry Syrup formulation. The result for the assay of CF, CT is shown in Table 3. The assay results obtained for CF, CT in the syrup formulation using the HPLC and UV spectroscopic methods. 
Tab. 3. Assay of syrup formulation

\begin{tabular}{||c||c||c||}
\hline Formulation Label Claim & *RSD $\%$ & Recovery $(\%) \pm$ SD \\
\hline \hline Zinamed $(125 \mathrm{mg} \backslash 5 \mathrm{~mL})$ & 0.01 & $105.40 \pm 0.05$ \\
\hline \hline Zednad $(250 \mathrm{mg} \backslash 5 \mathrm{~mL})$ & 0.38 & $105.13 \pm 0.19$ \\
\hline \hline Zenamed $(500 \mathrm{mg} \backslash \mathrm{tab})$ & 0.04 & $104.80 \pm 0.02$ \\
\hline \hline Sopraxymed(100mg $\backslash 5 \mathrm{~mL})$ & 1.76 & $106.60 \pm 0.87$ \\
\hline \hline Sopraxymed $(200 \mathrm{mg} \backslash 5 \mathrm{~mL})$ & 1.01 & $106.00 \pm 0.86$ \\
\hline Sopraxymed(400mg $\backslash \mathrm{Cap})$ & 0.93 & $100.80 \pm 0.46$ \\
\hline
\end{tabular}

* Average of three determination at each level.

\subsection{Conclusion}

Three novel analytical methods were developed for the determination of (CF, CT). The validation study shows the methods are specific, linear, precise, accurate, and sensitive in the proposed working range. The methods were found to be fast, simple, accurate, precise, and sensitive. The excipients present in the commercial formulation were found to be non-interfering in the assay results. The methods were successfully applied for the determination of the drug in dry syrup formulation. Furthermore, the developed methods may be applied for the routine analysis of the drug in API, formulations, and dissolution medium.

\section{Acknowledgement}

The authors are thankful to Medico Labs, Homs, Syria for providing the gift sample of Cefuroxime axetil, Cefixime trihydrate and Al-Baath University, Faculty of Science, Homs, Syria for providing the research facilities.

\section{References}

[1] Sweetman S, editor. (2009). Antibacterials. In: Martindale-The Complete Drug Reference.36th ed. London: Pharmaceutical Press, 218.

[2] Shukla SK, Quraishi MA. (2010). Cephalexine drug a new and efficient corrosion inhibitor for mild steel in hydrochloric acid solution. Mater Chem Phys, 120: 142-147.

http://dx.doi.org/10.1016/j.matchemphys.2009.10.037

[3] Alwarthan AA, Fattah SA, Zahran NM. (1992). Spectrophotometric determination of Cephalexine in dosage forms with imidazole reagent. Talanta. 39:703-707.

http://dx.doi.org/10.1016/0039-9140(92)80085-r

[4] Saleh GA, Askal HF, Radwan MF, Omar MA. (2001). Use of charge transfer complexation in the spectrophotometric analysis of certain cephalosporins. Talanta. 54: 1205-1215.

http://dx.doi.org/10.1016/s0039-9140(01)00409-x

[5] Attama AA, Nnamani PO, Agbo AN. (2006). Development of alternative assay technique for Cephalexine by charge transfer interaction of the donor: acceptor type with chloranilic acid.

Chin Pharm J. 58: 11-18.

[6] Priyanka P, Suresh P. (2008). Development of colorimetric method for Cephalexine in dosage forms. Asian J Pharm. 2: 120-122.

http://dx.doi.org/10.4103/0973-8398.42500

[7] Al-Ghannam SM. (2008). Spectrophotometric and Atomic Absorption Spectrometric Determination of Cephalexine and Cephradine in Dosage Forms.

J Food Drug Anal. 16: 19-25.

[8] Omar MA, Abdelmageed OH, Attla TZ. (2009). Kinetic spectrophotometric determination of certain cephalosporins in pharmaceutical formulations. Int J Anal Chem. 1-12.

http://dx.doi.org/10.1155/2009/596379

[9] El-Shaboury SR, Mohammed FA, Saleh GA, Rageh AH. (2010). Kinetic spectrophotometric determination of certain cephalosporins using iodate/iodide mixture. Natural Science. 2: 432-443.

http://dx.doi.org/10.4236/ns.2010.25053

[10] Al-Momani IF. (2001). Spectrophotometric determination of selected cephalosporins in drug formulations using flow injection analysis.

J Pharm Biomed Anal. 25: 751-757. http://dx.doi.org/10.1016/S0731-7085(01)00368-5

[11] Al-Othman ZA, Abdalla MA. (2011) Oxidative coupling for the spectrophotometric determination of certain cephalosporins and acitaminophen in drug formulations.

Arabian J Chem. 4: 239-242. http://dx.doi.org/10.1016/j.arabjc.2010.07.014

[12] Issopoulos PB. (1988). Spectrophotometric determination of certain cephalosporins using molybdophosphoric acid. Analyst. 113: 1083-1086. 
http://dx.doi.org/10.1039/an9881301083

[13] Sun Y, Tang Y, Yao H, Zheng X. (2004). Potassium permanganate-glyoxal chemiluminescence system for flow injection analysis of cephalosporin antibiotics: Cephalexine, cefadroxil, and cefazolin sodium in pharmaceutical preparations.

Talanta. 64: 156-159.

http://dx.doi.org/10.1016/j.talanta.2004.02.012

[14] Fei Q, Li M, Wang B, Huan Y, Feng G, Ren Y. (2009). Analysis of Cephalexine with NIR spectrometry coupled to artificial neural networks with modified genetic algorithm for wavelength selection.

Chemometr Intell Lab. 97: 127-131. http://dx.doi.org/10.1016/j.chemolab.2009.03.003

[15] Abdel Gaber AA, Farghaly OA, Ghandour MA, El-Said HS. (2000). Potentiometric studies on some cephalosporin complexes. Monatsh Chem. 131: 1031-1038.

http://dx.doi.org/10.1016/0022-0728(60)85468-x

[16] Nunez-Vergara L, Squella JA, Silva MM. (1982). Polarography of an acidic degradation product from Cephalexine. Talanta. 29: 137-138.

http://dx.doi.org/10.1016/0039-9140(82)80036-2

[17] Mendez JH, Perez AS, Zamarreno MD, Laso LV. (1984). Differential pulse polarographic determination of Cephalexine based on the catalytic pre-wave of nickel(II).

Anal Chim Acta. 160: 335-340. http://dx.doi.org/10.1016/s0003-2670(00)84541-9

[18] Miyazaki K, Ohtani K, Sunada K, Arita T. (1983). Determination of ampicillin, amoxicillin, Cephalexine, and cephradine in plasma by high-performance liquid chromatography using fluorometric detection.

J Chromatogr. 276: 478-482. http://dx.doi.org/10.1016/s0378-4347(00)85120-8

[19] Rouan MC. (1988). Microbore liquid chromatographic determination of cadralazine and Cephalexine in plasma with large volume injection.

J Chromatogr. 426: 335-344. http://dx.doi.org/10.1016/s0378-4347(00)81960-x

[20] Leroy P, Decolin D, Nicolas S, Archimbault P, Nicolas A. (1989). Residue determination of two coadministered antibacterial agents - Cephalexine and colistin - in calf tissues using high-performance liquid chromatography and microbiological methods.

J Pharm Biomed Anal. 7: 1837-1846. http://dx.doi.org/10.1016/0731-7085(89)80201-8

[21] Olsen BA, Baertschi SW, Riggin RM. (1993). Multidimensional evaluation of impurity profiles for generic Cephalexine and cefaclor antibiotics. J Chromatogr. 648: 165-173.

http://dx.doi.org/10.1016/0021-9673(93)83298-7

[22] Hsu MC, Lin YS, Chung HC. (1995). High performance liquid chromatographic method for potency determination of Cephalexine in commercial preparations for stability studies.

J Chromatogr A. 692: 67-72. http://dx.doi.org/10.1016/0021-9673(94)00688-6

[23] Gallo-Martinez L, Sevillano-Cabeza A, Campins-Falco P, Bosch-Reig F. (1998). A new derivatization procedure for determination of Cephalexine with 1,2-naphthoquinone-4- sulphonate in pharmaceutical and urine samples using solid-phase extraction catridges and UV-visible detection.

Anal Chim Acta. 370: 115-123. http://dx.doi.org/10.1016/s0003-2670(98)00276-1

[24] Samanidou VF, Hapeshi EA, Papadoyannis IN. (2003). Rapid and sensitive high-performance liquid chromatographic determination of four cephalosporin antibiotics in pharmaceuticals and body fluids.

J Chromatogr B. 788: 147-158. http://dx.doi.org/10.1016/s1570-0232(02)01040-1

[25] Qi M, Wang P, Sun P, Liu X. (2006). Liquid chromatographic method for the simultaneous determination of Cephalexine and trimethoprim in dog plasma and application to the pharmacokinetic studies of a coformulated preparation. J Chromatogr B. 832: 307-312. http://dx.doi.org/10.1016/j.jchromb.2006.01.012

[26] Patel A, Sahoo U, Patel N, Patel M, Seth AK. (2011). A study on impurity profile of Cephalexine. Curr Pharm Res. 1: 180-184.

[27] Changqin H, Shaohong J, Kaimin W. (1994). The chromatographic behavior of cephalosporins in gel filtration chromatography, a novel method to separate high molecular weight impurities.

J Pharm Biomed Anal. 12: 533-541. http://dx.doi.org/10.1016/0731-7085(94)80032-4

[28] Jeswani RM, Sinha PK, Topagi KS, Damle MC. (2009). A validated stability indicating HPTLC method for determination of Cephalexine in bulk and pharmaceutical formulation.

Int J PharmTech Res. 1: 527-536.

[29] Andrasi M, Buglyo P, Zekany L, Gaspar A. (2007). A comparative study of capillary zone electrophoresis and $\mathrm{pH}$-potentiometry for determination of dissociation constants.

J Pharm Biomed Anal. 44: 1040-1047. http://dx.doi.org/10.1016/j.jpba.2007.04.024

[30] Becker M, Zittlau E, Petz M. (2004). Residue analysis of 15 penicillins and cephalosporins in bovine muscle, kidney and milk by liquid chromatography-tandem mass spectrometry.

Anal Chim Acta. 520: 19-32. http://dx.doi.org/10.1016/j.aca.2004.04.022

[31] Kantiani L, Farre M, Freixiedas JMG, Barcelo D. (2010). Development and validation of a pressurised liquid 
extraction liquid chromatography-electrospray- tandem mass spectrometry method for $\beta$-lactams and sulfonamides in animal feed. J Chromatogr A. 1217: 4247-4254.

http://dx.doi.org/10.1016/j.chroma.2010.04.029

[32] Wu SG, Lai EP, Mayer PM. Molecularly imprinted solid phase extraction-pulsed elution-mass spectrometry for determination of Cephalexine and alpha-aminocephalosporin antibiotics in human serum.

J Pharm Biomed Anal. 200; 15: 483-490. http://dx.doi.org/10.1016/j.jpba.2003.05.001

[33] International Conference on Harmonization (ICH). ICH Harmonized Tripartite Guideline.

Topic Q2(R1).Validation of Analytical Procedures: Text and Methodology. Geneva,Switzerland 2005.

http://www.ich.org/products/guidelines/quality/quality-single/article/validation-of-analytical-procedures- textand-methodology.html. 